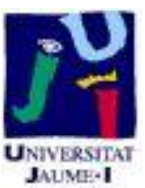

Título artículo / Títol article: Dissemination of information and visibility of the European Higher Education Area through the websites of Spanish universities: a longitudinal metric analysis, 2007-2012

Autores / Autors:

María Pinto, David Guerrero Quesada, Ximo Granell

Revista:

Scientometrics, (2014) 98

Versión / Versió:

Postprint del autor

Cita bibliográfica / Cita bibliogràfica (ISO 690):

PINTO, María; GUERRERO QUESADA, David;

GRANELL, Ximo. Dissemination of information and visibility of the European Higher Education Area through the websites of Spanish universities: a longitudinal metric analysis, 2007-2012.

Scientometrics, 2014, vol. 98, Issue 2, p. 1235-1255. 


\title{
Dissemination of information and visibility of the European Higher Education Area through the websites of Spanish universities: a longitudinal metric analysis, 2007-2012
}

\author{
María Pinto • David Guerrero Quesada · Ximo Granell
}

Received: 10 April 2013

(C) Akadémiai Kiadó, Budapest, Hungary 2013

\begin{abstract}
This paper draws on the findings from previous research work to present the UNIWEEES tool, designed to evaluate the quality of university websites that provide information about the European Higher Education Area (EHEA), already a reality, and the way they disseminate this information. This tool includes seven criteria (visibility, authority, updatedness, accessibility, dissemination of information, quality assessment, and navigability), further divided into 29 subcriteria that include 60 indicators. A peer-to-peer expert unified evaluation methodology was followed. Findings are presented here, focusing on the strengths and weaknesses of the information provided about the EHEA by the websites of Spanish universities and their dissemination strategies, in particular through their evolution along the last 5 years. Conclusions highlight a number of best practices identified and provide some guidelines to improve the evaluated aspects and dimensions, thus strengthening the role played by the university websites as quality information sources for the scholar community and the society.
\end{abstract}

Keywords Quality assessment · Web evaluation - UNIWEEES tool · European Higher Education Area $\cdot$ Spanish universities $\cdot$ Dissemination of information

\section{Introduction}

Past, present and future key challenges of the European Higher Education Area (EHEA) are briefly raised in the present work. The foundations of the EHEA were laid down in the

\footnotetext{
M. Pinto $(\square)$

Facultad de Comunicación y Documentación, Department of Information Science,

University of Granada, Paseo de Cartuja, s/n, 18071 Granada, Spain

e-mail: mpinto@ugr.es

D. Guerrero Quesada

Centro de Magisterio La Inmaculada, Granada, Spain

X. Granell

Department of Translation and Communication, Universitat Jaume I, Castellón, Spain
} 
Bologna Declaration (1999) and further revised in the Prague Declaration (2001). The following key areas were highlighted:

- System of easily readable and comparable degrees, essentially based on two main cycles: undergraduate and graduate studies.

- Promotion of mobility among European citizens by the introduction of a diploma supplement.

- Common system of credits.

- Recognition of qualifications throughout Europe to provide graduates with access to the jobs they are qualified for, regardless of the European country they might be living, and under the same conditions as the nationals of such country.

- Quality assurance: promotion of European cooperation to ensure high quality and comparable standards. Quality assurance agencies play a crucial role in this matter.

- Promotion of a European dimension in higher education, particularly focused on the development of curricula.

- Commitment to foster lifelong learning.

- Development of mobility action plans addressed to all members of the higher education community.

The subsequent Berlin Declaration (2003), Bergen Declaration (2005), London Declaration (2007), and Leuven/Louvain-la-Neuve Declaration (2009) communiqués broadened the agenda and added new challenges. After the Budapest-Vienna Declaration (2010) the EHEA was formally launched and became a reality for the higher education systems of the Bologna Process participating countries. It is well known that the main aim is to increase the compatibility and comparability among higher education systems while respecting their diversity so that an open space ensures the mobility of students, graduates, teachers, researchers and administrative staff. Since then, 47 countries have joined efforts and undertaken significant changes to achieve this goal. The results have recently been analysed by the Bucharest Declaration (2012), where an emphasis was placed on the need for developing strategies to enhance the employability of graduates and to strengthen mobility among institutions. According to this communiqué, quality assurance is essential for building trust and to reinforce the attractiveness of the EHEA's offerings and should be based on better quality of available data and improved information about higher education.

As it was expected, the introduction of the EHEA has generated a vast amount of documents in all participating countries, such as reports and declarations, published by a large number of bodies, ranging from the Ministers responsible for higher education, the European Commission, the European University Association (EUA) or European Students' Unions, to the Conference of Rectors of Spanish Universities (CRUE) or the Spanish National Agency for Quality Assessment and Accreditation (ANECA).

The EHEA requires a great organisation and systematisation effort to make good use of all the information and documentation generated. For this reason, Spanish universities devoted a space of their websites to the EHEA, in some cases without any previous work for defining a web information model. Such spaces could follow a vertical structure of information, presenting all the required and updated information, or a multiple layers model, organised in several areas (teaching, research, management, mobility). In any case, universities must define standards to gather and disseminate information in order to avoid redundancies and gaps, as well as to identify the relevant sets of information for each area. According to the standards and guidelines for quality assurance in the EHEA defined by the European Association for Quality Assurance in Higher Education (ENQA), higher education institutions should ensure that they collect, analyse and use relevant information 
for the effective management of their programmes of study and other activities, and that they should regularly publish up to date, impartial and objective information of the programmes and degrees they are offering.

To this end, ANECA (2012) developed MONITOR, a programme to supervise the implementation of the university degrees, designed as a methodological framework that allowed a suitable monitoring of this process. Thus, the proposed assessment tool included a number of dimensions and aspects subject to assessment, as well as assessment questions and scales.

The aim of the present paper is to examine the evolution of the EHEA along the last five years drawing on the information maid publicly available through the websites of Spanish universities, both as a source of information for the academic community and as a marketing and content dissemination tool for the society as a whole. Therefore, we draw on the findings of a previous study (Pinto et al. 2007) to address the following questions, among other issues: What relevant information about the EHEA is available at the websites of Spanish universities? Is it accessible to all users? Are available contents up to date? Do websites provide a simple and intuitive access to the information?

From this standpoint, we have carried out two qualitative studies, in two different moments, aimed at, firstly, verifying the suitability of the information provided by Spanish universities through their EHEA dedicated websites; and secondly, evaluating the evolution undergone by these web spaces.

\section{Literature review}

Internet information is characterized by the instability of its contents, decentralization of locations, multiplicity of forms, diversity of user groups, and dynamics of the environment (Zhang and Dimitroff 2005). However, the quality of this huge amount of information available at the Internet is not always as good as expected, partly due to the fact that there are no available guidelines for guaranteeing the quality of web resources (or, at least, they are not always taken into consideration).

The ease of publication on the Web highlights the need for a critical evaluation of the quality of information online. It is essential to be aware of the desirable features of university websites and the evaluation criteria that can be used to determine its value and usefulness. Given the importance of quality web resources as a way of disseminating information, particularly of scientific nature, this issue has been thoroughly examined in the past and it has been stated that a proper evaluation is required (McMurdo 1998).

Following this line of thought, Smith (1997) designed a set of criteria to evaluate the quality of web-based resources and classified them in seven categories: scope, content, graphic design, purpose and audience, reviews, workability, and cost. Miller (1996) focused on a number of dimensions that may determine the relevance and accuracy of web resources: timeliness (being up to date), completeness and format, coherence (how well the information hangs together), accessibility, compatibility (how information can be combined with other information), security, and validity (i.e. if information can be verified as being true).

Other authors, such as Alexander and Tate (1999), Beck (1997), and Kapoun (1998) propose five essential criteria (accuracy, authority, objectivity, currency, and coverage), along with a number of associated indicators to measure them. 
Nielsen's heuristic criteria (2000) have also been widely used to design quality websites:

- Visibility. The system should always keep users informed about what is going on, through appropriate feedback within reasonable time.

- Match between system and the real world. The system should speak the users' language, with words, phrases and concepts familiar to the user, rather than systemoriented terms. Real-world conventions should be followed, making information appear in a natural and logical order.

- User control and freedom. Users should have the possibility to leave the system without having to go through an extended dialogue and be able to perform undo and redo actions.

- Consistency. A uniform terminological criterion should be followed, and formal or legal jargon should be avoided whenever is possible.

- Error prevention.

- Recognition. Objects, actions, and options should remain visible. Sitemaps can help in this matter.

- Flexibility and efficiency of use. User profiles should be considered, adapting the type of information, the way its organised and its design to user needs.

- Aesthetic. A suitable and minimalist design should be used and should not contain information that is irrelevant or rarely needed.

- Help users recognize, diagnose, and recover from errors.

- Help and documentation. An easy access to support information, virtual assistants, and navigation guides should be provided.

Pitschmann and Federation (2001) classifies evaluation criteria for web resources into four categories: context (provenance and relationship to other resources), content (validity, accuracy, authority, uniqueness, completeness, coverage, currency, and audience), accessibility (site composition and organisation, navigational features, recognized standards and appropriate technologies, user support, terms and conditions, and rights legitimacy), and technical criteria (information, site, and system integrity).

Alternatively, Baeza Yates and Rivera (2002) state that web evaluation should focus on these five criteria:

- Usability measures the degree of efficiency, efficacy, and satisfaction experienced by a user when interacting with a website to fulfil his/hers objectives. Web usability, particularly from the pedagogical perspective, has been revisited by a number of authors (Kukulska-Hulme and Shield 2004; Nokelainen 2006; Wang and Chen 2009), who propose a number of quality criteria that deal with clarity, coherence, ease of navigability, identifiability, customisation... According to Nielsen and Tahir (2002), website usability is a quality attribute that measures the ease of use of the web interface, a view which is shared by scholars who look at home page perceptions of users (Singh et al. 2005).

- Visibility the system must keep users permanently informed about any circumstance, providing any relevant feedback within a reasonable time scale. Therefore, interaction with users is essential.

- Content should heavily rely on the quality of the information provided and on the absence of spelling and grammar mistakes, as well as on a careful presentation of the information, including an abstract, keywords, and a navigable table of contents.

- Aesthetics a plain, clear, and systematic design should be used. 
- Loyalty user satisfaction helps to engage and retain visitors.

Dragulanescu (2002) suggests the following evaluation criteria: accuracy, authority, coverage, currentness, density, interactivity, objectivity, and promptness. However, McInerney and Bird (2005) identify nine: content, functionality, currency and stability, links, graphics, authority, coverage, style, and meta-tags. Similarly, Wang and Chen (2009) use the following criteria as those significant for the evaluation of web-based resources: authority, content, currency, usability, design, and user friendliness. This set of features seeks to provide an accessible, easy to use, clear and friendly website to users in order to engage them and make them return. Ho et al. (2009) emphasise the importance of a homogeneous web design with clear and consistent navigation options and well-structured contents to enhance user navigability and ease of use. They also highlight the relevance of graphical and cognitive features of the interface and the presence of a powerful search engine to search contents within the website and boost user friendliness.

There exists ample literature on the design of indicators and models to evaluate websites of different domains. There are some interesting studies focusing on libraries (Chao 2002; Clausen 1999; Olsina et al. 1999), on companies (Barnes and Vidgen 2001, 2002; Miranda González and Bañegil Palacios 2004), and on the field of medicine (Jadad and Gagliardi 1998; Kim et al. 1999; Haddow 2003; Bernstam et al. 2005). However, education is the main area of knowledge where scientific production is truly extensive when focusing on website evaluation and on the evaluation of web-based educative resources, such as learning objects. Some outstanding international studies are: Branch et al. (1999), British Columbia (2002), Markland (2004), Lind (2005), Hosie and Schibeci (2005), Nokelainen (2006), Reinders and Lewis (2006), and Li et al. (2006). Similarly, some remarkable studies addressed to the Spanish territory are: Area et al. (2002), Marquès Graells (2002), Marzal et al. 2008, Padrón Nápoles (2009), Pinto and Gómez-Camarero (2011), and Pinto et al. (2012).

\section{Method}

Since the aim of this work is to obtain a picture of how Spanish public universities have evolved in terms of using their websites as a channel for disseminating information about the EHEA, we have decided to present the findings or this research following the seven criteria used in our previous study (Pinto et al. 2007), which was focused on the visibility of the EHEA. Hence, we can realise the current state of the art of each of the analysed criteria at Spanish public universities and see how they have improved their use of websites as an efficient source of information.

\section{The UNIWEEES tool}

This tool consists of a revised version of the tool used back in 2007, which was tested for evaluating its suitability for the present study. After conducting an updated review of the literature and a pilot study, the structure of the tool was still deemed valid for the achieving the objectives of the study. However, a number of items were not considered as having the same value as in the former study and a decision was made to remove them from the tool. In order to be able to compare the findings of both studies the scores obtained were taken into consideration as percentages of the potential maximum score of each criterion, not as absolute values. 
The resulting evaluation tool was named UNIWEEES and included a set of criteria, sub criteria, and weighted scores. It is made of seven main criteria, further divided into $29 \mathrm{sub}$ criteria that are assessed in accordance with the scores provided by 60 indicators. Such indicators were selected in keeping with the context of analysis. Those focusing on the Dissemination of the EHEA relied on a study of the documents deemed essential for the EHEA, which provided a clear outlook of the key issues of European convergence and of the terminology employed.

The tool uses Yes/No questions such as: 'Is a particular X feature available?' or 'Does the website meet a particular $\mathrm{X}$ requirement?' Then, positive answers of the indicators are added up for each criterion.

Each indicator is accordingly weighted (Table 1), since some issues have been considered to be more important than others. Each positive answer is codified as having the value ' 1 ' and each negative answer as ' 0 '. Those sections dealing with important issues receive a positive value of ' 2 '. As a result, we come up with a total score for each university. Taking into consideration all the criteria, the maximum score that can be achieved by a university is 82 points. These scores allow us to determine the level of visibility.

The criterion visibility of the information about the EHEA tells us whether the EHEA dedicated website of each university is easily accessible from its home page.

The criterion authority refers to the person or entity in charge of the development of the website and to the corporative image of the university. Updatedness measures whether the EHEA website is up to date, whether users can be aware of the date of the last update, or whether links are regularly checked to avoid dead links.

The criterion about accessibility is bound to the regulations stated by the norm UNE 139803 (AENOR 2012), which sets a number of accessibility criteria for websites that Spanish public universities and the bodies of Spanish public administration must meet. Therefore, it is checked whether this obligation is present in the design of EHEA websites. Additionally, the continuous development of technology led us to adapt one of the criteria from the previous study to change the indicator about the availability of printable versions. The growing access to the web through mobile devices means that users should be able to save information in a downloadable format for offline access. In the same way, in this setting of increased mobility, common printers are not as handy as they used to be. As a consequence, it was decided to ask about the possibility of saving web content as a PDF file.

The criterion dissemination of the EHEA and its sub criteria and indicators were drawn from the basic objectives of the EHEA stated in the official documents previously referred to.

This is the criterion that has experienced a larger amount of modifications. From 2007, the EHEA has grown exponentially to become the backbone of the new Spanish university. Its contents have evolved in such a way that today almost every activity undertaken by universities is related to it. This fact demanded a redefinition of this criterion to reflect the current situation, so the following three criteria were removed from the tool:

- Analysis of the first 10 hits in search engines. The development of new web authoring tools and the relevance given by some commercial areas to rank on top of search engine results have led to the possibility of positioning any website on top of the results offered by search engines like Google. This means that the position of an institution is not an indicator of the quality of the work undertaken by its web developers any more.

- Programmes. The continuous evolution of the EHEA has led to assign the diverse programmes that are part of it to a number of different services within each university. 
Table 1 The UNIWEEES tool

\begin{tabular}{|c|c|c|}
\hline Code & Criteria & Value \\
\hline 1 & Visibility of the information about the EHEA & \\
\hline 1.1 & Access from home page & \\
\hline 1.1 .1 & It is available & 1 \\
\hline 1.1 .2 & It is easy to find & 1 \\
\hline 1.1 .3 & The term used is clearly identifiable. & 1 \\
\hline 1.2 & Access to second level of information & \\
\hline 1.2 .1 & The place where it is shown on the home page has a self-explanatory title & 1 \\
\hline 1.3 . & Overall sitemap of the University website & \\
\hline 1.3 .1 & It is available & 1 \\
\hline 1.3 .2 & The sitemap has links to the contents & 1 \\
\hline 1.3 .3 & In the section about the EHEA & 1 \\
\hline 1.4 & Table of contents of the University & \\
\hline 1.4 .1 & It is available & 1 \\
\hline 1.4 .2 & $\begin{array}{l}\text { A comment to the link (section) is available for briefly identifying or describing its content } \\
\text { using keywords }\end{array}$ & 1 \\
\hline 1.4 .3 & The information is arranged in sections that open up hierarchically & 1 \\
\hline 1.5 . & Table of contents of the EHEA & \\
\hline 1.5 .1 & It is available & 2 \\
\hline 1.5 .2 & $\begin{array}{l}\text { A comment to the link (section) is available for briefly identifying or describing its content } \\
\text { using keywords }\end{array}$ & 2 \\
\hline 1.5 .3 & The information is arranged in sections that open up hierarchically & 2 \\
\hline 1.6 & Internal search engine & \\
\hline 1.6 .1 & The university has a general search engine & 1 \\
\hline 1.6 .2 & $\begin{array}{l}\text { A proprietary search engine is available or it is possible to search only within the EHEA } \\
\text { section }\end{array}$ & 1 \\
\hline 1.6 .3 & The search engine has advanced search features. There is a list of keywords & 1 \\
\hline 1.7 & Metadata & \\
\hline 1.7.1. & They are used & 1 \\
\hline 2 & Authority & \\
\hline 2.1. & The University's logo and name are visible in every page about the EHEA & \\
\hline 2.1 .1 & The University's logo and name are visible in every page & 2 \\
\hline 2.2 & Webmaster is stated in the EHEA home page & \\
\hline 2.2 .1 & Webmaster is stated & 1 \\
\hline 3 & Updatedness & \\
\hline 3.1 & Updating of information & \\
\hline 3.1 .1 & The date of the last update is visible & 2 \\
\hline 3.2 & Dead links & \\
\hline 3.2 .1 & There are no links beyond one month old & 2 \\
\hline 3.2 .2 & It is stated whether the deadlines involved in announcements have finished or not & 2 \\
\hline 4 & Accessibility & \\
\hline 4.1 & Compatible design with several browsers/screen resolutions & \\
\hline 4.1.1 & There are no distortions when viewing the home pages (Firefox, Explorer) & 1 \\
\hline 4.1 .2 & $\begin{array}{l}\text { There are no information formats that may cause access problems (Flash, etc.); there are } \\
\text { viewing alternatives }\end{array}$ & 1 \\
\hline
\end{tabular}


Table 1 continued

\begin{tabular}{|c|c|c|}
\hline Code & Criteria & Value \\
\hline 4.2 & $\begin{array}{l}\text { Regulations about site accessibility for all (recommendations of the WAI, http://w3c.org/ } \\
\text { WAI) }\end{array}$ & \\
\hline 4.2 .1 & There are guidelines on how to use the site available & 2 \\
\hline 4.3 & Printable versions are available & \\
\hline 4.3.1 & It is possible to save contents as a PDF file & 1 \\
\hline 4.4. & Help on the web structure and navigation & \\
\hline 4.4.1 & It is available & 1 \\
\hline 4.5 . & Different languages can be selected (example: Spanish/English; Catalan/Spanish) & \\
\hline 4.5 .1 & An English version is available & 1 \\
\hline 4.5.2 & There are versions in the co-official languages (Basque, Catalan, Galician, Valencian) & 1 \\
\hline 4.5 .3 & Contents are the same in all the languages & 1 \\
\hline 5 & Dissemination of the EHEA & \\
\hline 5.1 & General information & \\
\hline 5.1 .1 & A postal address is provided & 1 \\
\hline 5.1 .2 & An e-mail address is provided & 1 \\
\hline 5.1 .3 & A list of services is available & 1 \\
\hline 5.1 .4 & An explanation of the EHEA is provided & 1 \\
\hline 5.1 .5 & Participation in the institutional framework (MEC, ANECA, Quality standards agencies) & 1 \\
\hline 5.1 .6 & Specific links & 1 \\
\hline 5.1.6.1 & Number & \\
\hline 5.2 & Regulations & \\
\hline 5.2 .1 & There is a dedicated section & 2 \\
\hline 5.2 .2 & They are arranged according to programmes & 2 \\
\hline 5.2 .3 & Links to the documents & 2 \\
\hline 5.2 .4 & Links to related institutions (Ministries, European Union, etc.) & 2 \\
\hline 5.2 .5 & Links to specific software required to view the documents (Adobe) & 2 \\
\hline 5.3 & Congresses, seminars, conferences, workshops & \\
\hline 5.3 .1 & Calendar of events & 2 \\
\hline 5.3 .2 & Updated information & 2 \\
\hline 5.4 & Announcements & \\
\hline 5.4 .1 & Specific to the University & 2 \\
\hline 5.4 .2 & Outcomes/follow-up & 2 \\
\hline 5.4 .3 & National & 2 \\
\hline 5.4 .4 & Outcomes/follow-up & 2 \\
\hline 5.4 .5 & European & 2 \\
\hline 5.4 .6 & Outcomes/follow-up & 2 \\
\hline 5.5 & Highlighting important information (Latest news/News) & \\
\hline 5.5 .1 & It is available & 1 \\
\hline 6 & Quality Assessment & \\
\hline 6.1 & Quality policy statement on the website & \\
\hline 6.1 .1 & It is available & 1 \\
\hline 6.2. & Suggestion box & \\
\hline 6.2 .1 & It is available & 1 \\
\hline
\end{tabular}


Table 1 continued

\begin{tabular}{cll}
\hline Code & Criteria & Value \\
\hline 6.3. & Survey on user satisfaction about the website & 1 \\
6.3 .1 & It is available & 1 \\
6.4 & Availability of a dedicated strategic plan for the service & \\
6.4 .1 & It is available & 1 \\
6.5 & Website requirements specification for the service & \\
6.5 .1 & It is available & 2 \\
7. & Navigability & 2 \\
7.1. & Menu of contents always visible & 1 \\
7.1 .1 & On all pages & \\
7.1 .2 & In the same place & 1 \\
7.2. & Consistent terminology & \\
7.2 .1 & The same term is used in every section & \\
7.3. & Navigation buttons & It is possible to go back to an upper level \\
7.3 .1 &
\end{tabular}

Keeping track of these programmes and sub programmes carried out by each university is beyond the scope of the present work.

- Similarly, the same reason has also motivated the removal of the criterion 'Directory of people in charge of programmes/projects', since this information should be published on the website of the service responsible for each project.

The quality assessment criterion is one of the key features of the EHEA and, taking into consideration the Spanish Royal Decree 951/2005 of the 29 July, we believed it was important to be aware of the relevance given to the quality by each university's website. In order to accommodate current quality assessment trends, two new items were added to the 2007 tool, namely, the availability of a dedicated strategic plan and the list of services provided.

Finally, the navigability criterion was used to check whether users can find their way around the website, know where they are at any time, and know how to reach the information they seek.

Data collection

Once the tool was refined, next step involved gathering all the required information from the websites of the Spanish public universities.

Table 2 Scale for assessing criteria

\begin{tabular}{lll}
\hline Percentage & Score & Assessment \\
\hline From 0 to $20 \%$ & 1 & Unacceptable (U) \\
From 21 to $40 \%$ & 2 & Bad (B) \\
From 41 to $60 \%$ & 3 & Acceptable (A) \\
From 61 to $80 \%$ & 4 & Good (G) \\
From 81 to $100 \%$ & 5 & Excellent (E) \\
\hline
\end{tabular}


Table 3 Overall findings: detailed scores by criteria

\begin{tabular}{lcccl}
\hline Criterion & Years & $\begin{array}{l}\text { Maximum } \\
\text { score }\end{array}$ & Score & $\begin{array}{l}\text { Percentage } \\
(\%)\end{array}$ \\
\hline Visibility & 2012 & 20 & 11.5 & 58 \\
& 2007 & 20 & 9.07 & 45 \\
Authority & 2012 & 3 & 1.7 & 57 \\
& 2007 & 3 & 2.10 & 70 \\
Updatedness & 2012 & 6 & 0.8 & 13 \\
& 2007 & 6 & 2.59 & 43 \\
Accessibility & 2012 & 9 & 4.7 & 52 \\
Dissemination & 2007 & 9 & 3.68 & 41 \\
& 2012 & 33 & 9.99 & 30 \\
Quality assessment & 2012 & 5 & 27.57 & 52 \\
& 2007 & 3 & 1 & 20 \\
Navigability & 2012 & 6 & 0.60 & 20 \\
& 2007 & 6 & 4.74 & 79 \\
& & & 3.91 & 65 \\
\hline
\end{tabular}

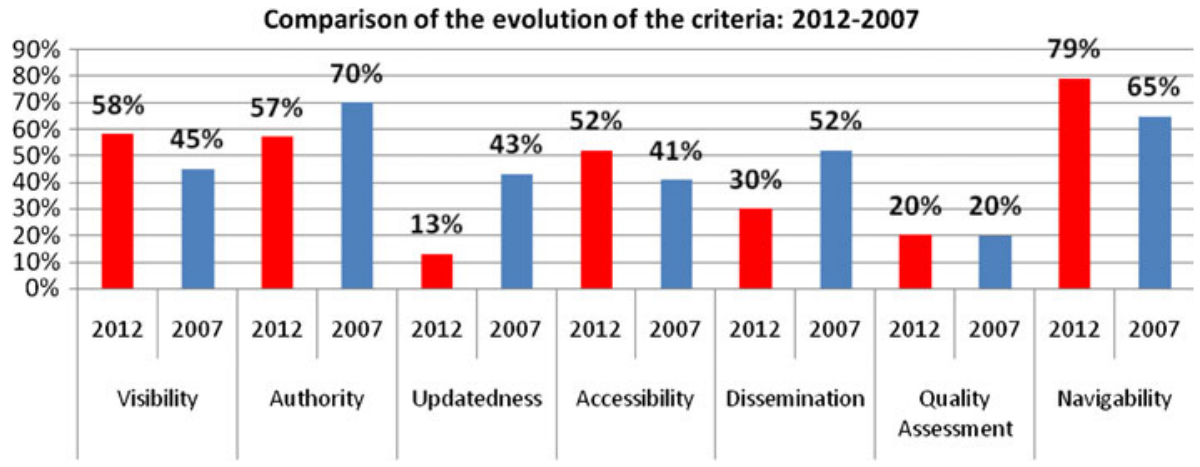

Fig. 1 Overall findings: comparison of the evolution of the criteria

The population of this research is made of the total number of Spanish public universities, i.e. 50 universities. The list of websites from these universities was obtained from the information provided by the Spanish Ministry of Education and Science (http:// www.mec.es) and was checked against the list published by the Conference of Rectors of Spanish Universities (http://www.crue.org).

Data collection was undertaken manually during the last quarter of 2011. The resulting findings were verified in all cases to preserve the legitimacy of the evaluation process. Data was collected by visiting each of the websites and seeking for the EHEA dedicated section within the website (when available). For those universities without a direct link to this information, internal search engines, available for the vast majority of them, were used. The Spanish search keywords used to this end were: 'Espacio Europeo de Educación Superior', 'Espacio Europeo de Enseñanza Superior', 'Convergencia Europea', 'Armonización Europea' (i.e. the Spanish terms for 'EHEA', 'European Convergence', and 


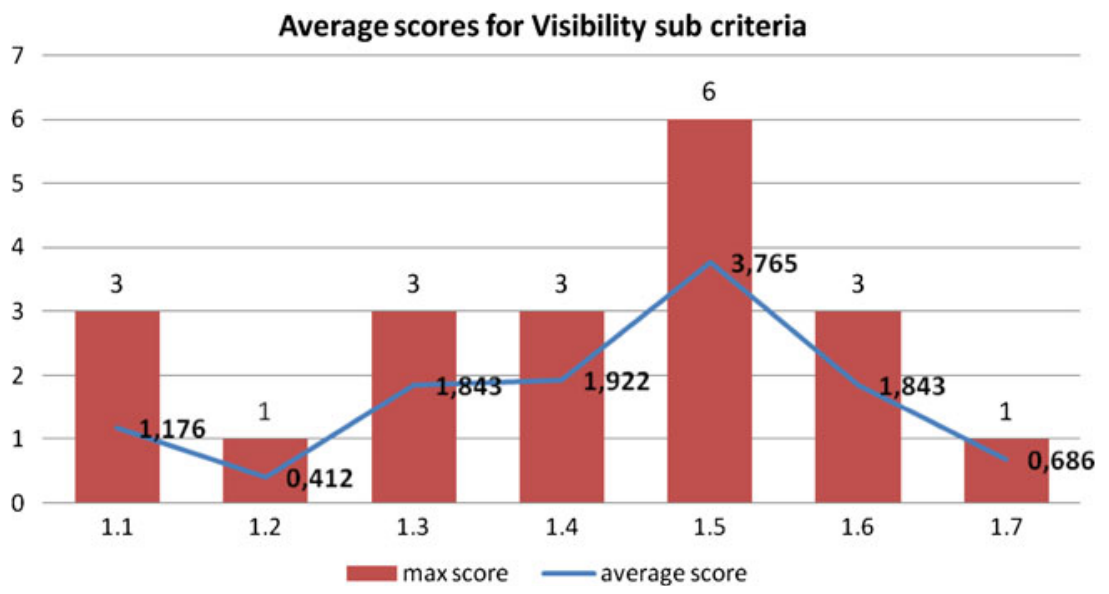

Fig. 2 Visibility sub criteria average scores

'European Harmonisation'). The terms were also translated for those universities in regions with a second official language:

Basque Espazioa Europar Hezkuntza Goikoa, Espazioa Europar Irakaskuntza Goikoa, Bateratasuna Europarra, Harmonizazio Europarra.

Catalan/Valencian Espai Europeu d'Educació Superior, Espai Europeu d'Ensenyament Superior, Convergència Europea, Harmonització Europea.

Galician Espazo Europeo de Educación Superior, Espazo Europeo de Ensino Superior, Converxencia Europea, Armonización Europea.

In the case for those universities with pages about the EHEA in different languages, all of them were visited to extract all the relevant information and it was stated whether the information was the same or not for each language.

In order to compute an average score for each university from the percentages obtained for each sub criterion, each criterion was assessed by a qualitative scale ranging from 1 to 5 as stated in Table 2 .

\section{Findings}

Table 3 and Fig. 1 present a detailed account of the scores obtained for each criterion and a comparison of the overall findings from the two studies carried out:

Criterion 1: visibility of information

In 2007 this dimension had an average score of 9.07 points, whereas in 2012 its score rose to 11.5 points. In percentage terms, the visibility of the websites about the EHEA has risen from $45 \%$ of the maximum score to $58 \%$, which shows a clear commitment among Spanish public universities to provide access to this information.

An in-depth analysis of the proposed seven sub criteria provides a detailed breakdown of the visibility criterion: 
1. Linking to the resource from the home page of the university is the easiest way of facilitating the access to it and a suitable way of informing visitors/users of the latest news. The process followed to develop the EHEA has ended up assigning its key issues to separate services within each university, so 19 of them provided a direct link that was easy to find and identify.

2. As for accessing to second-level information, there are mixed findings again: 20 universities have a place in their home page with a self-explanatory title that refers to the EHEA.

3. Undoubtedly, the main progress in this criterion is shown by the use of content sitemaps of both, universities' websites (35) and dedicated spaces about the EHEA (21).

4. This also happens with tables of contents. The websites of all universities but five provide this tables and their information is fairly well arranged.

5. Surprisingly, only three EHEA-specific websites do not provide this type of tables at this level of detail, their information is also well arranged overall, and they include explanatory notes to their links. This is probably due to the fact that universities' websites are authored by several people.

6. Whereas the visibility sub criteria analysed so far followed browsing methods to find information, the two remaining sub criteria refer to another way of finding information, namely, by performing fast and accurate searches. In first place, $93.5 \%$ of the universities had an internal search engine, a fact that remains the same as in the previous study, although the number of universities with advanced search features and that can restrict the results to the EHEA section has grown to 37 of them. Secondly, all universities have added metadata to these websites, so it is easier to describe and identify them, and what matters more, retrieve this data through search engines.

All in all, the main weaknesses identified by the previous study (i.e. a lack of sitemaps on universities' home pages, the capabilities of their search engines, and the characteristics

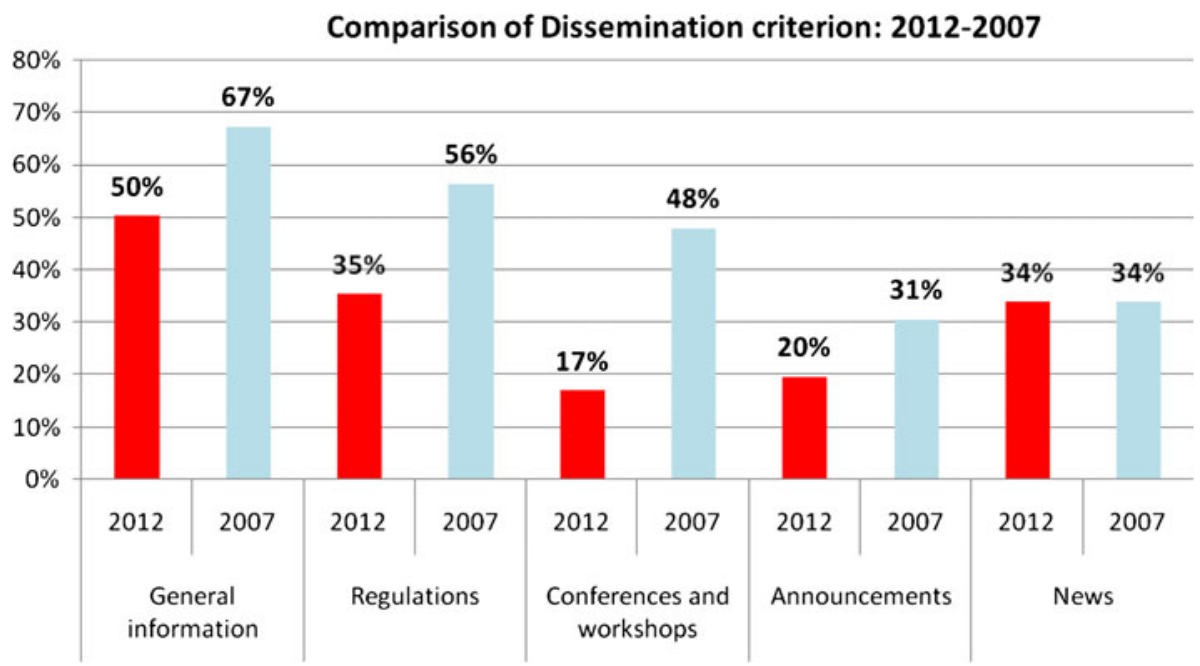

Fig. 3 Evolution of dissemination of EHEA information 
of the tables of contents about the EHEA) have been solved thanks to the evolution of web authoring tools.

Figure 2 shows the average score for each Visibility sub criterion (c.f. Table 1) in comparison with the maximum score in each case.

Criterion 2: authority

Overall, this aspect was neglected when universities designed their new websites. Whereas in 2007 the score was of 2.1 out of 3 points $(70 \%)$, in this study this score has dropped to 1.7 out of 3 , i.e. a $10 \%$ lower score.

37 Universities (88 \%) show their logo and name on the EHEA website, so the institution responsible for this resource is clearly stated.

However, webmaster details continue to be unusual and only 10 universities $(24 \%)$ provide this information on their EHEA websites. This is an improvement that most universities should care about, since this information allows users to contact those in charge of the maintenance of the resource in case of errors or problems.

Table 4 Ranking of criteria by university

\begin{tabular}{|c|c|c|}
\hline Criterion & 2007 & 2012 \\
\hline \multirow[t]{3}{*}{ Visibility } & Alcalá de Henares (Uah) & Las Palmas de Gran Canaria (Uplgc) \\
\hline & Politécnica de Cataluña (Upc) & Córdoba (Uco) \\
\hline & Barcelona (Ub) & Jaén (Ujaen) \\
\hline \multirow[t]{3}{*}{ Authority } & Politécnica de Cataluña (Upc) & Rovira i Virgili (Urv) \\
\hline & Barcelona (Ub) & Pública de Navarra (Unavarra) \\
\hline & Oviedo (Uniovi) & Valencia Estudi General (Uv) \\
\hline \multirow[t]{3}{*}{ Updatedness } & Extremadura (Unex) & Castilla-La Mancha (Uclm) \\
\hline & Cádiz (Uca) & Córdoba (Uco) \\
\hline & Autónoma de Madrid (Uam) & Huelva (Uhu) \\
\hline \multirow[t]{3}{*}{ Accessibility } & Extremadura (Unex) & Autónoma de Barcelona (Uab) \\
\hline & Sevilla (Us) & Roviria i Virgili (Urv) \\
\hline & Rey Juan Carlos (Urjc) & Girona (Udg) \\
\hline \multirow[t]{3}{*}{ Dissemination } & Alicante (Ua) & Huelva (Uhu) \\
\hline & Valladolid (Uva) & Alicante (Ua) \\
\hline & Valencia Estudi General (Uv) & Málaga (Uma) \\
\hline \multirow[t]{3}{*}{ Quality assessment } & Burgos (Ubu) & Almería (Ual) \\
\hline & Alcalá de Henares (Uah) & Alicante (Ua) \\
\hline & Valladolid (Uva) & Valencia Estudi General (Uv) \\
\hline \multirow[t]{3}{*}{ Navigability } & Alcalá de Henares (Uah) & Almería (Ual) \\
\hline & Valencia Estudi General (Uv) & Valencia Estudi General (Uv) \\
\hline & A Coruña (Udc) & Jaume I (Uji) \\
\hline \multirow[t]{3}{*}{ Overall } & Alicante (Ua) & Huelva (Uhu) \\
\hline & Valladolid (Uva) & Córdoba (Uco) \\
\hline & Valencia Estudi General (Uv) & Málaga (Uma) \\
\hline
\end{tabular}


Criterion 3: updatedness

As in the previous study, it was found that universities' style sheets do not show updatedness as a key issue when designing their websites. The reason for this does not have to do with obsolete contents (only $14 \%$ of the visited websites had some links older than a month), but with the fact that it is not a common practice to show the date of the last update (17\% showed it, against $26.7 \%$ in the previous study) or to state whether the deadlines involved in announcements are over (this is only shown by $19 \%$ of the websites, in comparison with $33 \%$ of them in the previous study).

The average score of this criterion is 0.84 out of 6 points, meaning that this issue has worsened in comparison with the score obtained in 2007.

\section{Criterion 4: accessibility}

This is one of the most improved points of the visited websites. Scores have increased from an average of 3.6 out of 9 to 4.7 out of 9 , indicating an improvement of $12 \%$.

$100 \%$ of the universities have websites that are fully compatible with web browsers (i.e. they show the same display in internet explorer and in other browsers), unlike $15.6 \%$ of them in the previous study.

Table 5 Ranking of criteria by region

\begin{tabular}{|c|c|c|}
\hline Criterion & 2007 & 2012 \\
\hline Visibility & $\begin{array}{l}\text { Basque Country } \\
\text { Catalonia } \\
\text { Madrid }\end{array}$ & $\begin{array}{l}\text { La Rioja } \\
\text { Basque Country } \\
\text { Navarre }\end{array}$ \\
\hline Authority & $\begin{array}{l}\text { Basque Country } \\
\text { Balearic Islands } \\
\text { Castille-La Mancha }\end{array}$ & $\begin{array}{l}\text { Castille-La Mancha } \\
\text { Navarre } \\
\text { Extremadura }\end{array}$ \\
\hline Updatedness & $\begin{array}{l}\text { Extremadura } \\
\text { Balearic Islands } \\
\text { Valencia }\end{array}$ & $\begin{array}{l}\text { Castille-La Mancha } \\
\text { Extremadura } \\
\text { Andalusia }\end{array}$ \\
\hline Accessibility & $\begin{array}{l}\text { Extremadura } \\
\text { Navarre } \\
\text { Valencia }\end{array}$ & $\begin{array}{l}\text { Basque Country } \\
\text { Asturias } \\
\text { Castille-La Mancha }\end{array}$ \\
\hline Dissemination & $\begin{array}{l}\text { Valencia } \\
\text { Basque Country } \\
\text { Murcia }\end{array}$ & $\begin{array}{l}\text { Extremadura } \\
\text { Andalusia } \\
\text { Valencia }\end{array}$ \\
\hline Quality Assessment & $\begin{array}{l}\text { Murcia } \\
\text { Balearic Islands } \\
\text { Navarre }\end{array}$ & $\begin{array}{l}\text { Valencia } \\
\text { Basque Country } \\
\text { Andalusia }\end{array}$ \\
\hline Navigability & $\begin{array}{l}\text { Navarre } \\
\text { Extremadura } \\
\text { Galicia }\end{array}$ & $\begin{array}{l}\text { Basque Country } \\
\text { La Rioja } \\
\text { Catalonia }\end{array}$ \\
\hline Overall & $\begin{array}{l}\text { Extremadura } \\
\text { Valencia } \\
\text { Basque Country }\end{array}$ & $\begin{array}{l}\text { Extremadura } \\
\text { Andalusia } \\
\text { Catalonia }\end{array}$ \\
\hline
\end{tabular}


The number of universities that declare to follow WAI regulations by using the corresponding logo has risen from 20 to $60 \%$.

$89 \%$ of the universities allow saving contents to a PDF file.

Online help is an important asset that allows users to find solutions to their troubles and make the most of this information resource. This has also been considered by universities, since $59 \%$ of them have it available, unlike $20 \%$ of them in 2007.

Communicating information in several languages is gaining more and more relevance. As a consequence $48 \%$ of the websites have an English version available and $70 \%$ of them provide the same information in both languages. All the universities from regions with co-official languages have fully bilingual websites.

Criterion 5: dissemination of the EHEA

Due to the evolution of the EHEA, previously discussed, this section is the one that has experienced more changes. Only 5 out of 8 sub criteria from the original study have been assessed this time.

The evolution of the dissemination of EHEA-related information can be seen in the Fig. 3.

All the sub criteria, except for 'News' have obtained lower scores than in 2007.

Criterion 6: quality assessment

When comparing current data with the findings from 2007, no major improvements have occurred, even though quality assessment is very important for the EHEA. From a 0.6 out of 3 points score, current data present an average score of 1.16 out of 5 points (hardly $23 \%$ of the maximum score).

As a positive note, $33 \%$ of the services hold a quality assessment certification and $48 \%$ provide a suggestion box to their users.

\section{Criterion 7: navigability}

Scores for this criterion also show a considerable improvement: from 3.9 out of 6 points to 3.73 out of 4 (i.e. an increase of $28 \%$ ).

This change is mostly due to the wider use of navigation menus that are always available on all pages (from 66.7 to $95 \%$ ) and to the use of navigation buttons ( $88 \%$ against $26.7 \%$ ).

Best practices

Table 4 presents a ranking of universities according to the best practices for each of the criteria and identifies those ones that hold the best three scores.

Table 6 Improved and worsened universities

\begin{tabular}{lc}
\hline Improved universities & Worsened universities \\
\hline $\begin{array}{l}\text { Uab; uclm; uco; udg; udl; uhu; ujaen; ulpgc; uma; } \\
\text { unileon; unirioja; usal }\end{array}$ & $\begin{array}{c}\text { Ua; uam; ub; ugr; unavarra; unex; uniovi; upc; } \\
\text { upo; uv; uva; uvigo }\end{array}$ \\
\hline
\end{tabular}


The same comparison was also made at regional level (i.e. among Spanish Autonomous Communities) and the following findings were obtained:

Another interesting finding shows that those universities in regions with their own quality assessment agency score, on average, higher than those without this way of assuring quality (35.68 against 28.33).

\section{Discussion of results in comparison with related research}

In addition to the contrast with the results of previous research (Pinto et al. 2007), further discussed in the next section, there are several studies with related research that might provide interesting comparisons. Two of the authors of this paper also adapted the methodology of this research to focus on evaluating the information provided by Spanish public universities on the web about their assessment and quality processes (Pinto et al. 2005,2009 ) and found out unsatisfactory results for those indicators focused on pages dealing with assessment, quality and the EHEA. Therefore, the results of the present work contribute to present a more detailed picture and further explain the issues related to the EHEA (Table 5).

There are also similar proposals of web evaluation addressed to particular types of websites, such as archives websites (Caballero and Pérez 2012). This study focuses on the very specific characteristics of this type of website to propose a model identifying 100 items that can be used to evaluate it, although no results of its application are provided yet. Similarly, more specific assessment of some indicators has also been researched, such as the accessibility of Spanish universities websites (Ribera et al. 2009; Térmens Graells et al. 2007), which were deemed to be low in terms of level of accessibility and compliance with standards and guidelines between the years 2001 and 2006. Our research, on the contrary, shows that there has been a significant and progressive increase in meeting accessibility requirements since 2007 , from a $20 \%$ to a $60 \%$ in 2012 , probably due to the changes of Spanish laws to improve access to information at the beginning of 2007.

Some studies have used other metric indicators to evaluate universities' websites, such as Payne and Thelwall (2007), who looked at the changes experienced by the static pages of UK, Australian and New Zealand academic webs from 2000 to 2005 to state that academic spaces may have a longer-term validity than would have been previously

Table 7 Comparison of types of information

\begin{tabular}{llll}
\hline & Years & Average score & $\begin{array}{l}\text { Percentage } \\
(\%)\end{array}$ \\
\hline General information & 2012 & 3.02 & 50 \\
& 2007 & 4.04 & 67 \\
Regulations & 2012 & 3.54 & 35 \\
Conferences and & 2007 & 5.64 & 56 \\
workshops & 2012 & 0.68 & 17 \\
Announcements & 2007 & 1.92 & 48 \\
& 2012 & 2.36 & 20 \\
News & 2007 & 3.68 & 31 \\
& 2012 & 0.34 & 34 \\
& 2007 & 0.34 & 34 \\
\hline
\end{tabular}


assumed, according to webometric analysis (i.e. using mathematical and visual techniques). This type of analysis somehow is confirming that even though updatedness issues have not been assessed very positively in our later research, the good visibility overall assessment of the web pages might be partly due to the persistence of this type of data over time.

Other studies have also paid attention to formal quality indicators of academics webs, but only to those that can be obtained automatically, mainly addressed to analyse link networks, through techniques that fall into the so called cybermetrics or webometrics. The are examples focusing on university library websites in Spain (González-Lucio et al. 2009), Arab universities in the Middle East and North African region (AL-Dwairi et al. 2010), the visibility and impact of universities' websites in social platforms (Orduña-Malea and Ontalba-Ruipérez 2013), or even more closely related issues, such as mapping the web presence of the EHEA at universities (Ortega et al. 2008). Conclusions drawn from this type of studies, though, are usually aimed at generalising or determine the impact of the websites in terms of how connected they are among them or the evidences of regional affinities.

\section{Conclusions and recommendations}

In keeping with the objectives of the present work stated at the beginning of this paper, we can conclude that:

The aim of this paper is to examine the evolution of the EHEA along the last five years from the information published by Spanish public universities through their websites, both in terms of being a source of information for the academic community and in terms of a being a marketing and content dissemination tool addressed to the society as a whole.

Data collected and presented in the findings of the paper allow us to infer that universities have not followed steady criteria in maintaining EHEA related websites, since only one university (Alicante) has remained among the top three in one of the criteria: dissemination. Table 6 presents the list of those universities that have improved their scores and of those ones that have worse scores in comparison with the results of 2007.

What relevant information about the EHEA is available at the websites of Spanish universities?

Although the technical aspects of the study reveal an overall improvement, it seems clear that a backward movement has been made when looking at content-related information on

Table 8 Qualitative assessment of criteria

\begin{tabular}{llll}
\hline & Overall assessment & Number of universities & $\begin{array}{l}\text { Percentage of } \\
\text { universities }(\%)\end{array}$ \\
\hline Criterion 1: visibility & Good & 19 & 38 \\
Criterion 2: authority & Good & 28 & 56 \\
Criterion 3: updatedness & Unacceptable & 33 & 66 \\
Criterion 4: accessibility & Good & 19 & 38 \\
Criterion 5: dissemination & Bad & 21 & 42 \\
Criterion 6: quality assessment & Unacceptable & 36 & 72 \\
Criterion 7: navigability & Excellent & 40 & 80 \\
\hline
\end{tabular}


the EHEA dedicated websites. In all five types of information analysed the scores for 2012 are clearly lower than those for 2007, except for the section about News, where a percentage of $34 \%$ remains the same (Table 7 ).

Is the information collected accessible to all users?

Universities' websites can be viewed without distortions regardless of the web browser used. $60 \%$ of the universities state they are WAI-compliant, so their information should be accessible to any user, regardless of the platform of access and the disabilities users may have. There is no doubt about the close relationship between this fact and the commencement of Spanish laws to improve access to information at the beginning of 2007.

These laws have been gathered together at http://accesibilidadweb.dlsi.ua.es/ index.php?menu=espanola.

Are available contents up to date?

It is difficult to be aware of the degree of updatedness of the information found at these websites, since only $17 \%$ of the assessed universities show the date when their contents have been updated.

Do websites provide a simple and intuitive access to information?

Universities have improved this aspect in general. They do not only provide easier access to information and better visibility of the pages (from $45 \%$ in 2007 to $58 \%$ in 2012), but also an improved navigation through the several parts of the website (increasing scores from $65 \%$ in 2007 to $79 \%$ in 2012).

To sum up, the evolution of websites as a way for disseminating information can be studied from two perspectives: technically and content wise. Technical aspects present a much clearer improvement. Accessibility and navigability show a clear trend towards new ways of designing websites, focusing on an easier and more inclusive user experience.

However, the use of websites as a way for disseminating information has gone a step backwards. Again, two angles could be differentiated. First, we could focus on the socalled 'netiquette', which in our study deals with showing the responsible of the website to the user (authority) and the date when contents were updated (updatedness). In both cases current findings present worse scenarios than in 2007. In second place, we have the information that should be communicated to users, the main reason for publishing a particular website.

If we examine these findings according to the qualitative scale stated in the method section, an overall assessment for each criterion can be stated. Table 8 presents a summary of this information.

Websites still have a long way to go before they fulfil all the criteria identified by the literature about the features that all websites must have.

We cannot forget here that universities are going to be assessed according to the information published on their websites and that this will serve as a verification of their commitment towards quality. As a matter of fact, ANECA, through its programme MONITOR, is going to assess the implementation of new degrees in accordance with the information published by universities on their websites. 


\section{References}

AENOR. (2012). Requisitos de accesibilidad para contenidos en la web: UNE 139803:2012. Madrid: AENOR.

AL-Dwairi, K.M.O., Faba-Pérez, C., \& Vargas-Quesada, B. (2010). Formal cybermetic indicators of the positioning of Arab universities. Investigación Bibliotecológica, 24(52), 145-171.

Alexander, J. E., \& Tate, M. A. (1999). Web wisdom: how to evaluate and create web page quality on the web. Hillsdale: Erlbaum.

ANECA. (2012). Programa MONITOR: Guía de apoyo. ANECA. Retrieved June 26, 2012, from http:// www.aneca.es/content/download/12342/151996/file/guia_monitor_120416.pdf.

Area, M., Castro, F., De La Cruz, A., Sanabria, A., \& Estévez, R. (2002). Análisis de webs docentes de tecnología Educativa y Nuevas Tecnologías aplicadas a la educación de las universidades españolas. Work presented at X Jornada del Profesorado de Tecnología Educativa, Barcelona.

Baeza Yates, R., \& Rivera, C. (2002). Ubicuidad y usabilidad en la web. Retrieved Feb 15, 2013, from http://users.dcc.uchile.cl/ rbaeza/inf/usabilidad.html.

Barnes, S. J., \& Vidgen, R. T. (2001). An evaluation of cyber-bookshops: The webqual method. International Journal of Electronic Commerce, 6(1), 11-30.

Barnes, S. J., \& Vidgen, R. T. (2002). An integrative approach to the assessment of e-commerce quality. Journal of Electronic Commerce Research, 3(3), 114-127.

Beck, S. (1997). The good, the bad and the ugly, or, why it's a good idea to evaluate web sources. Retrieved Feb 15, 2013, from http://lib.nmsu.edu/instruction/eval.html..

Bergen Declaration. (2005). The European Higher Education Area-achieving the goals: Communiqué of the conference of European ministers responsible for higher education, Bergen, 19-20 May 2005. http://www.ehea.info/Uploads/Declarations/Bergen_Communique1.pdf. Accessed 26 March 2013.

Berlin Declaration. (2003). Realising the European Higher Education Area: Communiqué of the conference of ministers responsible for higher education in Berlin on 19 September 2003. http://www.ehea.info/ Uploads/Declarations/Berlin_Communique1.pdf. Accessed 26 March 2013.

Bernstam, E. V., Shelton, D. M., Walji, M., \& Meric-Bernstam, F. (2005). Instruments to assess the quality of health information on the world wide web: what can our patients actually use? International Journal of Medical Informatics, 74(1), 13-20.

Bologna Declaration. (1999). The European Higher Education Area: Communiqué of the conference of ministers responsible for higher education in Bologna on 19 June 1999. http://www.ehea.info/Uploads/ Declarations/BOLOGNA_DECLARATION1.pdf. Accessed 26 March 2013.

Branch, R. M., Kim, D., \& Koenecke, L. (1999). Evaluating online educational materials for use in instruction. Syracuse: ERIC Clearinghouse on Information \& Technology.

British Columbia. (2002). Ministry of evaluating, selecting, and managing learning resources: A guide. Government of British Columbia.

Bucharest Declaration. (2012). Making the most of our potential: Consolidating the European Higher Education Area: Communiqué of the conference of European ministers responsible for higher education, Bucharest, 26-27 April 2012. http://www.ehea.info/Uploads/\%281\%29/Bucharest\%20 Communique\%202012\%281\%29.pdf. Accessed 29 June 2012.

Budapest-Vienna Declaration. (2010). Budapest-Vienna declaration on the European Higher Education Area. Retrieved Mar 12, 2010, from http://www.ehea.info/Uploads/Declarations/Budapest-Vienna_ Declaration.pdf. Accessed 23 April 2012.

Caballero, I. S., \& Pérez, C. F. (2012). Diseño de un modelo basado en criterios e indicadores de características para la evaluación de los sitios webs de archivos. Revista General de Información y Documentación, 22(0). doi:10.5209/rev_RGID.2012.v22.39660.

Chao, H. (2002). Assessing the quality of academic libraries on the web: The development and testing of criteria. Library \& Information Science Research, 24(2), 169-194. doi:10.1016/S0740-8188(02)001 11-1.

Clausen, H. (1999). Evaluation of library web sites: The danish case. The Electronic Library, 17(2), 83-87. doi:10.1108/02640479910329527.

Dragulanescu, N. G. (2002). Website quality evaluations: Criteria and tools. The International Information \& Library Review, 34(3), 247-254. doi:10.1006/iilr.2002.0205.

González-Lucio, J. A., Faba-Pérez, C., de Moya Anegón, F., \& Moscoso-Castro, P. (2009). Evolution of the formal quality indicators of the web spaces of University Libraries in Spain. Cybermetrics, 13(1). http://dspace.uah.es/dspace/handle/10017/2857. Accessed 26 April 2013.

Haddow, G. (2003). Focusing on health information: How to assess information quality on the internet. Australian Library Journal, 52(2), 169-178. 
Ho, W., Higson, H. E., Dey, P. K., Xu, X., \& Bahsoon, R. (2009). Measuring performance of virtual learning environment system in higher education. Quality Assurance in Education, 17(1), 6-29. doi:10.1108/ 09684880910929908.

Hosie, P., \& Schibeci, R. (2005). Checklist and context-bound evaluations of online learning in higher education. British Journal of Educational Technology, 36(5), 881-895. doi:10.1111/j.14678535.2005.00513.x.

Jadad, A.R., Cagliardi A. (1998). Rating health information on the internet: Navigating to knowledge or to babel? JAMA, 279(8), 611-614. doi:10.1001/jama.279.8.611.

Kapoun, J. (1998). Teaching undergrads WEB evaluation: A guide for library instruction. C\&Rl News, 59(7), 23.

Kim, P., Eng, T. R., Deering, M. J., \& Maxfield, A. (1999). Published criteria for evaluating health related web sites: Review. BMJ, 318(7184), 647-649. doi:10.1136/bmj.318.7184.647.

Kukulska-Hulme, A., \& Shield, L. (2004). Usability and pedagogical design: Are language learning websites special? In Proceedings of ED-MEDIA 2004 (pp. 4235-4242). Presented at ED-MEDIA 2004. http://telearn.archives-ouvertes.fr/hal-00190340. Accessed 15 Feb 2013.

Leuven/Louvain-la-Neuve Declaration. (2009). The bologna process 2020-The European Higher Education Area in the new decade: Communiqué of the conference of European ministers responsible for higher education, Leuven and Louvain-la-Neuve, 28-29 April 2009. http://www.ehea.info/Uploads/ Declarations/Leuven_Louvain-la-Neuve_Communiqu\%C3\%A9_April_2009.pdf. Accessed 26 March 2013.

Li, J. Z., Nesbit, J. C., \& Richards, G. (2006). Evaluating learning objects across boundaries. International Journal of Distance Education Technologies, 4(1), 17-30. doi:10.4018/jdet.2006010102.

Lind, L. (2005). Defining the quality of online learning material in Finland. In: Policy and Innovation Committee Meeting, Birminghan.

London Declaration. (2007). Towards the European Higher Education Area: Responding to challenges in a globalised world: Communiqué of the conference of European ministers responsible for higher education, London. Retrieved May 18, 2007, from http://www.ehea.info/Uploads/Declarations/ London_Communique18May2007.pdf. Accessed 26 March 2013.

Markland, M. (2004). Integrating digital resources into online learning environments to support the learner. Meetings \& proceedings; presentation. Retrieved Feb 19, 2013, from http://www.networkedlearning conference.org.uk/past/nlc2004/proceedings/symposia/symposium9/markland_kemp.htm.

Marquès Graells, P. (2002). Las webs docentes. Rerieved Feb 19, 2013, from http://peremarques.pangea.org/ webdocen.htm.

Marzal, M. Á., Calzada Prado, J., \& Vianello Osti, M. (2008). Criterios para la evaluación de la usabilidad de los recursos educativos virtuales: un análisis desde la alfabetización en información. Retrieved Feb 19, 2013, from http://e-archivo.uc3m.es:8080/handle/10016/4629.

McInerney, C. R., \& Bird, N. J. (2005). Assessing Website quality in context: Retrieving information about genetically modified food on the Web. Information Research, 10(2), 213.

McMurdo, G. (1998). Evaluating web information and design. Journal of Information Science, 24(3), 192-204. doi:10.1177/016555159802400306.

Miller, H. (1996). The multiple dimensions of information quality. Information Systems Management, 13(2), 79-82. doi:10.1080/10580539608906992.

Miranda González, F., \& Bañegil Palacios, T. (2004). Quantitative evaluation of commercial web sites: an empirical study of Spanish firms. International Journal of Information Management, 24(4), 313-328. doi:10.1016/j.ijinfomgt.2004.04.009.

Nielsen, J., \& Tahir, M. (2002). Homepage usability: 50 websites deconstructed (Vol. 50). New Riders Indianapolis, IN. http://www.lucastraining.es/herramientas/e_marketing/Website\%20Usability\%20 Guidelines,\%20Nielsen,\%20Tahir.pdf. Accessed 15 Feb 2013.

Nokelainen, P. (2006). An empirical assessment of pedagogical usability criteria for digital learning material with elementary school students. Journal of Educational Technology and Society, 9(2), 178.

Olsina, L., Godoy, D., Lafuente, G., \& Rossi, G. (1999). Quality characteristics and attributes for academic web sites. In web engineering workshop at WWW8, Toronto, Canada.

Orduña-Malea, E., \& Ontalba-Ruipérez, J.-A. (2013). Selective linking from social platforms to university websites: a case study of the Spanish academic system. Scientometrics, 95(2), 593-614. doi:10.1007/ s11192-012-0851-1.

Ortega, J. L., Aguillo, I., Cothey, V., \& Scharnhorst, A. (2008). Maps of the academic web in the European Higher Education Area: An exploration of visual web indicators. Scientometrics, 74(2), 295-308. doi:10.1007/s11192-008-0218-9.

Padrón Nápoles, C. L. (2009). Desarrollo de materiales didácticos desde una perspectiva basada en modelos. Doctoral Thesis. Retrieved Feb 19, 2013, from http://e-archivo.uc3m.es:8080/handle/10016/5679. 
Payne, N., \& Thelwall, M. (2007). A longitudinal study of academic webs: Growth and stabilisation. Scientometrics, 71(3), 523-539. doi:10.1007/s11192-007-1695-y.

Pinto, M., \& Gómez-Camarero, C. (2011). Propuesta de criterios e indicadores internacionales para la evaluación de los recursos educativos electrónicos. Ibersid: Revista de Sistemas de Información y Documentación, 5(0), 81-87.

Pinto, M., Berrocal, J. L. A., García, J. A. C., Marcial, V. F., Figuerola, C. G., Marco, J. G., et al. (2005). Quality assessment of Spanish universities' web sites focused on the European research area. Scientometrics, 65(1), 67-93. doi:10.1007/s11192-005-0260-9.

Pinto, M., Sales, D., Doucet, A.-V., Fernández-Ramos, A., \& Guerrero, D. (2007). Metric analysis of the information visibility and diffusion about the European Higher Education Area on Spanish University websites. Scientometrics, 72(2), 345-370. doi:10.1007/s11192-007-1766-0.

Pinto, M., Guerrero, D., Fernández-Ramos, A., \& Doucet, A.-V. (2009). Information provided by Spanish university websites on their assessment and quality processes. Scientometrics, 81(1), 265-289. doi:10.1007/s11192-008-2123-7.

Pinto, M., Gómez-Camarero, C., \& Fernández-Ramos, A. (2012). Los recursos educativos electrónicos: perspectivas y herramientas de evaluación. Perspectivas em Ciência da Informação, 17(3), 82-99.

Pitschmann, L. A., \& Federation, D. L. (2001). Building sustainable collections of free third-party web resources. Digital library federation, council on library and information resources. http://old.diglib.org/ pubs/dlf092/dlf092.pdf. Accessed 15 Feb 2013.

Prague Declaration. (2001). Towards the European Higher Education Area: Communiqué of the meeting of European ministers in charge of higher education in Prague on May 19th 2001. http://www.ehea.info/ Uploads/Declarations/PRAGUE_COMMUNIQUE.pdf. Accessed 26 March 2013.

Reinders, H., \& Lewis, M. (2006). An evaluative checklist for self-access materials. ELT Journal, 60(3), 272-278. doi:10.1093/elt/ccl007.

Ribera, M., Térmens, M., \& Frías, A. (2009). The accessibility of Spanish university web sites. A 2001-2006 assessment. Revista Espanola de Documentación Cientifica, 32(3), 66-88. doi:10.3989/ redc.2009.3.683.

Singh, S. N., Dalal, N., \& Spears, N. (2005). Understanding web home page perception. European Journal of Information Systems, 14(3), 288-302. doi:10.1057/palgrave.ejis.3000525.

Smith, A. G. (1997). Testing the surf: Criteria for evaluating Internet information resources. Public AccessComputer Systems Review, 8(3). https://journals.tdl.org/pacsr/article/view/6016/5645. Accessed 15 Feb 2013.

Térmens Graells, M., Ribera Turró, M., \& Sulé Duesa, A. (2007). Accessibility level of websites in the Spanish universities. Revista española de Documentación Cientifica, 26(1). doi:10.3989/ redc.2003.v26.i1.131.

Wang, Y., \& Chen, N.-S. (2009). Criteria for evaluating synchronous learning management systems: arguments from the distance language classroom. Computer Assisted Language Learning, 22(1), 1-18. doi:10.1080/09588220802613773.

Zhang, J., \& Dimitroff, A. (2005). The impact of metadata implementation on webpage visibility in search engine results (Part II). Information Processing and Management, 41(3), 691-715. doi:10.1016/ j.ipm.2003.12.002. 